\title{
Chapter 8 \\ Avian Diversity and Distributions and Their Evolution Through Space and Time
}

\author{
Manuel Schweizer and Yang Liu
}

\begin{abstract}
Most modern orders of birds evolved and diversified during the last 65 million years following the demise of the nonavian dinosaurs and pterosaurs at the Cretaceous-Paleogene boundary. Diversification rates in birds increased from c. 50 million years ago onward driven by significant rate increases in different clades scattered throughout the entire phylogeny. No slowdown in the overall diversification rate has been identified, and equilibrium diversity might not have been reached. Birds breed on all of the continents on Earth and have adapted to almost every habitat. Substantial variation in distribution patterns occurs among the different species, ranging from narrow-range endemics restricted to a single oceanic island or to a particular habitat within a small geographic area to species with a nearcosmopolitan distribution, breeding on almost all continents. As in most groups, diversity of bird species is greatest in tropical regions near the equator and decreases toward the poles. This pattern, termed the latitudinal diversity gradient, cannot be causally linked to a single mechanism and might be influenced by both evolutionary and ecological processes. Species richness within a given area is basically the result of speciation, extinction, and dispersal. Speciation commences with the accumulation of genetically based divergence between populations and is completed by the development of reproductive isolation among them. This usually involves a phase of geographic separation of populations without contact, a process termed allopatric speciation. Speciation with ongoing gene flow between populations, i.e., parapatric speciation, and especially the evolution of reproductive isolation without geographic separation, i.e., sympatric speciation, appear rare in birds. Distribution patterns of different bird groups particularly across the Southern Hemisphere have for a long time been interpreted as being the result of vicariance evolution. Vicariance is considered to be the split of a geographical range of a species via a barrier caused
\end{abstract}

M. Schweizer $(\triangle)$

Naturhistorisches Museum der Burgergemeinde Bern, Bern, Switzerland

e-mail: manuel.schweizer@nmbe.ch

Y. Liu

State Key Laboratory of Biocontrol, Department of Ecology, School of Life Sciences, Sun Yat-sen University, Guangzhou, P. R. China 
by a historical event like montane uplift or the formation of oceans through tectonic rifting. The formation of such barriers should promote episodes of allopatric speciation in multiple clades, generating congruent biogeographic patterns among them. Using dated phylogenetic hypotheses, however, several studies have recently revealed discordance between sequences of geological events and phylogenetic patterns. Consequently, only past dispersal events, often over long distances and across oceans, can explain the current distribution patterns of several avian groups. In general, landscape changes might not result in congruent temporal diversification patterns among different bird groups. It can be assumed that the older an avian lineage is, the more time it has to colonize an area across a barrier. This increases the likelihood of dispersal across the barrier and subsequent diversification on either side of the divide. In addition, bird groups with lower dispersal abilities are expected to accumulate genetic differences among populations at a higher rate than lineages with higher dispersal capability. Consequently, diversification patterns are the result of interactions between ecological properties of different avian lineages and their environment as well as the age of a given lineage. Geographic ranges of birds are generally limited by a suite of biotic and abiotic factors. Range expansion is not only an important first step in speciation but also influences the number of coexisting species and thereby shapes the turnover of biodiversity in space and time.

Keywords Avian diversification · Avian diversity · Avian distribution · Allopatric speciation - Parapatric speciation - Sympatric speciation · Vicariance - Dispersal · Colonization $\cdot$ Range evolution

\subsection{Spatiotemporal Diversification of Modern Birds}

Birds possess little resemblance to a Tyrannosaurus or a Stegosaurus; nonetheless modern birds, Neornithes, are the only surviving lineage of dinosaurs, forming a wellsupported monophyletic lineage (Mayr 2017). The initial divergence event within Neornithes comprised the split of Palaeognathae, the ratites and tinamous, from the remaining lineages called Neognathae (Fig. 8.1). Within the latter, there is a separation between the Galloanseres, containing all land- and waterfowl, and Neoaves, a clade encompassing all other extant birds. These basal phylogenetic relationships of modern birds are robustly supported by both morphological and molecular data (e.g., Cracraft 2001; Hackett et al. 2008; Jarvis et al. 2014; Livezey and Zusi 2007; Mayr 2011; Prum et al. 2015).

The clade of Neoaves comprises the majority of extant bird species and such ecologically and morphologically diverse groups as gulls, herons, hummingbirds, owls, parrots, penguins, pelicans, raptors, and songbirds. The phylogenetic relationships of the different basal lineages within Neoaves are still controversial and have not unambiguously been resolved, even when applying genome-wide molecular data (Jarvis et al. 2014; Prum et al. 2015). The difficulty in resolving the early branching pattern in the evolution of the different Neoaves lineages might be caused by their rapid and apparently near-simultaneous radiation following the Cretaceous-Paleogene (K-Pg) mass extinction of 65 million years ago (Ma) (Suh 2016). 


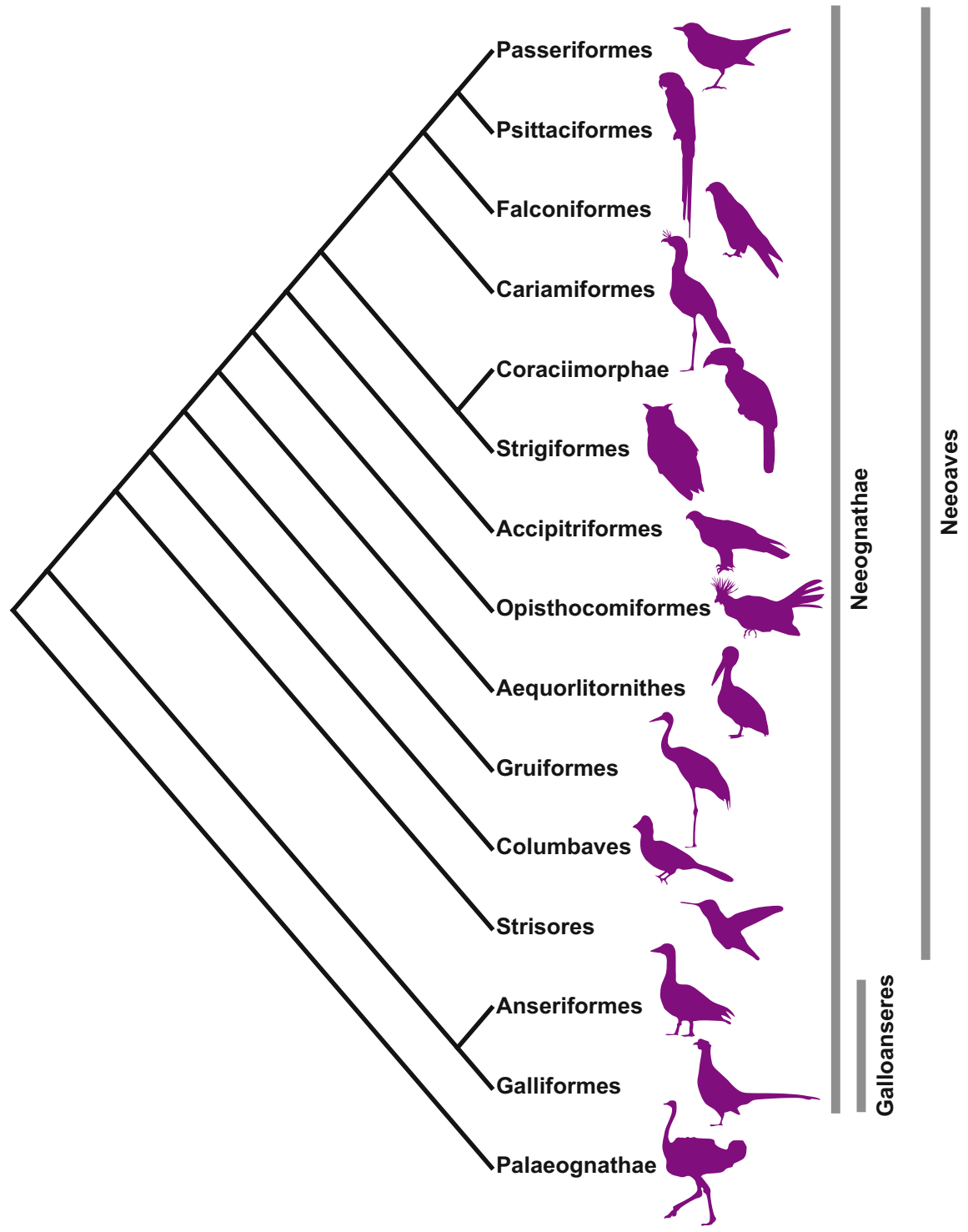

Fig. 8.1 Cladogram illustrating the phylogenetic relationships of the major clades of modern birds (Neornithes) redrawn and modified after Prum et al. (2015)

The mass extinction at the end of the Cretaceous was one of the three largest of the Phanerozoic (the last 541 million years) (Alroy 2008) and was triggered by the impact of a massive asteroid at Chicxulub, Mexico. It led to the disappearance of all dinosaur groups except modern birds and, among others, of pterosaurs, ammonites, and rudists (Schulte et al. 2010). A study of the fossil record led to the hypothesis 
that modern birds evolved via an explosive radiation among the few surviving lineages following this global perturbation (Feduccia 1995, 2003). However, this scenario was subsequently questioned by several molecular phylogenetic hypotheses, which dated the divergence among several crown clades of modern avian groups, including Passeriformes, before the K-Pg boundary (e.g., Brown et al. 2008; Cooper and Penny 1997; Pacheco et al. 2011; Pereira and Baker 2006; Pratt et al. 2009; Slack et al. 2006). Nevertheless, this is unlikely, because the fossil record demonstrates that the first Neornithine-like birds appeared c. 80-85 Ma in the late Cretaceous and resemble Palaeognathae (Mayr 2017). Definitive fossil evidence for the occurrence of Neognathae comes only from the Maastrichtian (72.1-66.0 Ma) (Mayr 2017). The results of recent molecular phylogenies based on genomic data calibrated using several conservatively chosen fossils, however, are more in line with the fossil record and date the basal divergence within Galloanseres, and the nearly simultaneous initial radiation of Neoaves, at the K-Pg mass extinction (Jarvis et al. 2014; Prum et al. 2015). This supports the hypothesis that the demise particularly of nonavian dinosaurs and pterosaurs at the K-Pg boundary generated an ecological opportunity that fostered explosive diversification. Consequently, modern birds rapidly filled the newly available vacant ecological niche space. Why Neornithes were the only lineage of dinosaurs that survived the late Cretaceous mass extinction event remains an open question.

Modern birds continued their spectacular diversification thereafter, and a dated phylogenetic hypothesis of the majority of extant species of birds has revealed that overall, diversification rates increased from approximately $50 \mathrm{Ma}$ onward (Jetz et al. 2012). This general increase was driven by significant rate increases among different clades scattered throughout the entire avian phylogenetic tree, i.e., in several clades of Passeriformes (passerines), Laridae (gulls terns and skimmers), Picidae (woodpeckers) and allies, Trochilidae (hummingbirds), Galloanseres (land- and waterfowl), Psittacidae (parrots), and Columbidae (pigeons and doves). Rate shifts often seem to have been related to key innovations or ecological opportunities. Moreover, Jetz et al. (2012) found that geographical variation in diversification rates is driven by hemispheric differences rather than latitudinal differences, with generally higher rates in the Western versus the Eastern Hemisphere and no overall difference between the Northern and Southern Hemispheres.

Generally, high diversification rates and a relatively high prevalence of clades with exceptional rates were revealed in parts of Northern Asia, high-latitude North America, and southwest South America, whereas lineages in Australia, Southeast Asia, Africa, and Madagascar display overall comparatively low diversification rates. Given an Australian or African origin for several ancient radiations, this may be the result of density-dependence effects on diversification. It is generally assumed that diversity (species richness) within a clade does not increase continuously with age, but might reach an equilibrium diversity regulated by ecological limits in a given area, resulting in diversity dependence of speciation and extinction rates and to a decoupling of clade age and species richness (Rabosky 2009). Overall, however, Jetz et al. (2012) revealed that opportunities for diversification in birds since the late Eocene (c. $50 \mathrm{Ma}$ ) appear not to be exhausted and that equilibrium diversity may not 
yet have been reached. Such a lack of any slowdown in diversification might be a general feature of (adaptive) radiations among single clades of birds at larger geographic scales, such as in dynamic continental ecosystems with continuous ecological opportunity (Bryson et al. 2014; Derryberry et al. 2011; Liu et al. 2016; Schweizer et al. 2014). However, a slowdown in diversification reflecting ecological saturation through competition for niche space might still be prevalent in clades at geographically confined scales (Jonsson et al. 2012; Phillimore and Price 2008; Price et al. 2014; Rabosky and Lovette 2008; Reddy et al. 2012; Weir 2006).

\subsection{Global Distribution and Diversity Patterns}

Birds are ubiquitous on Earth today, breed on all continents, and have adapted to almost all types of habitats. However, no single bird species can be considered to be truly cosmopolitan, i.e., occurring on all continents. Nonetheless, species such as the Peregrine Falcon Falco peregrinus, which breeds on all continents except Antarctica (del Hoyo and Collar 2014), or the Osprey Pandion haliaetus, which breeds on five continents and visits a sixth, South America, as a nonbreeding visitor, are virtually cosmopolitan. Additionally, some long-distance migrants and pelagic birds visit larger parts of the world during their annual migration cycles. On the other hand, species with only a very small distribution are called narrow endemics and are restricted to a small oceanic island or to a particular habitat within a small geographic area. As just one example, the Sombre Rock Chat Oenanthe dubia is today probably restricted to a small area in the Upper Awash Valley in Ethiopia where it lives only on rocky slopes with some grass and bushes (Collar and Sharpe 2017). Famous examples of distinctive oceanic island endemic passerine species with very restricted ranges and very tiny populations include Hawaiian honeycreepers and white-eyes on islands of the Pacific Ocean.

The early naturalists already realized that species are not randomly distributed, and they tried to divide the world into different regions characterized by distinct faunal (or floral) assemblages. Such a biogeographic regionalization can be considered one of the central aims of biogeography (Kreft and Jetz 2010). In 1858, the British ornithologist P.L. Sclater published the first global regionalization based on distributions of birds. This scheme was later adapted by A.R. Wallace (1867) for the global mammal fauna. Surprisingly, this original zoogeographic regionalization is still widely used, although several modifications have been published, implementing not only up-to-date species distribution information but also phylogenetic data in some cases and using different criteria for the delimitation of regions (e.g., Ficetola et al. 2017; Holt et al. 2013; Kreft and Jetz 2010; Vilhena and Antonelli 2015) (Fig. 8.2). The world is thereby divided into six principal biogeographic regions, the Nearctic, Neotropical, Palearctic, Afrotropical, Oriental, and Australasian regions. In terms of the number of endemic families, the Neotropical region is most unique (42 endemic families), followed by the Australasian (38), Afrotropical (27), Oriental (10), Palearctic (5), and Nearctic (1) regions (Winkler et al. 2015). Of course, 

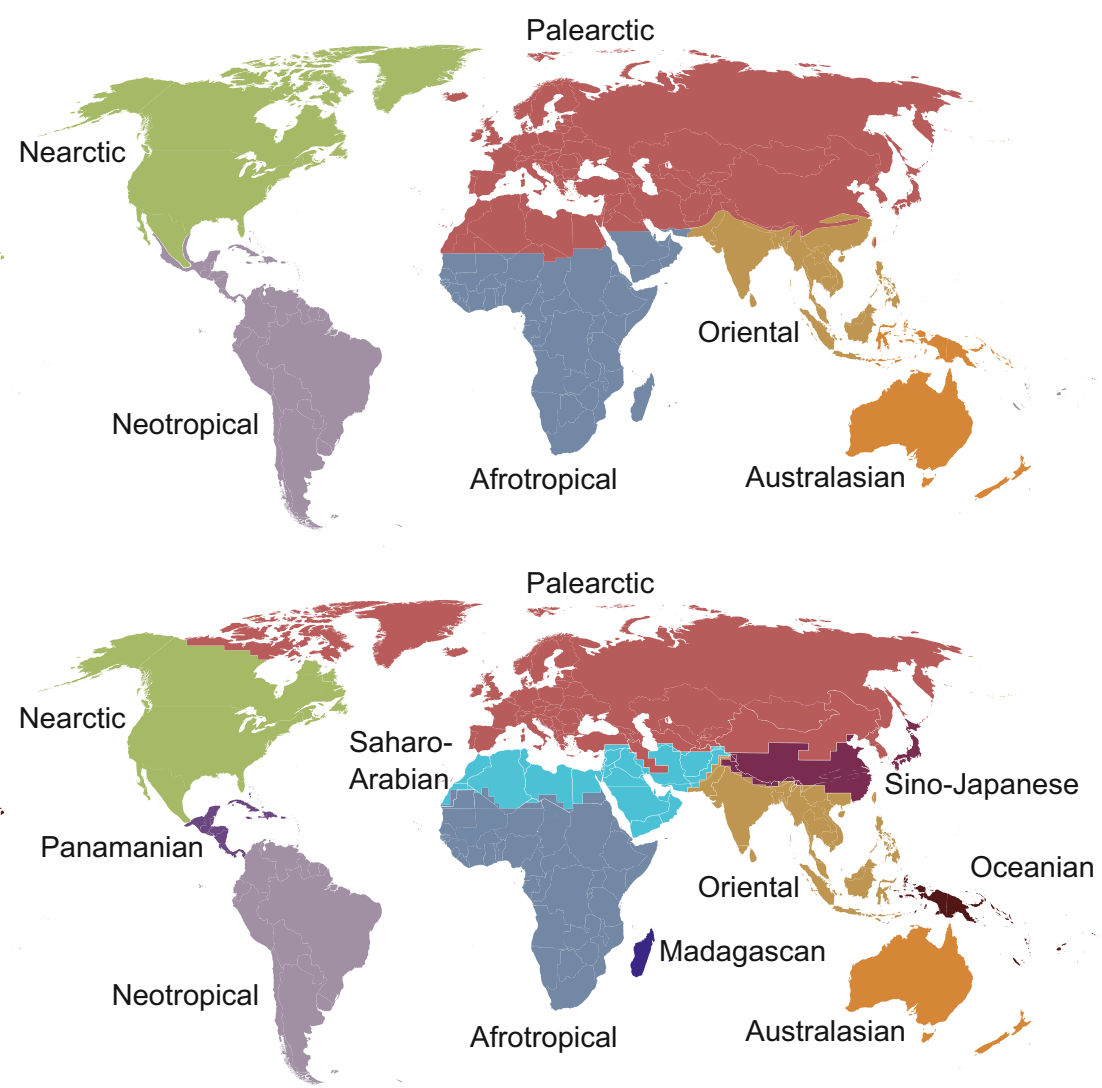

Fig. 8.2 Top: World map showing the six major biogeographic regions according to WWF (taken from https://en.wikipedia.org/wiki/Biogeographic_realm) basically following the original scheme by A.R. Wallace from 1876 (Wallace 1867). Bottom: An updated biogeographic regionalization by Holt et al. (2013) based on an integration of global distribution data and phylogenetic relationships of amphibian, non-pelagic birds, and nonmarine mammals. Redrawn after Holt et al. (2013)

these figures depend strongly on the taxonomic treatment applied. Species richness is also greatest in the Neotropics (Newton 2003), with the most diverse regions in Peru and Ecuador, where more than 600 species have been recorded within a few square kilometers (Bass et al. 2010; Greenberg 2016). The majority of avian diversity hotspots also lie in the Neotropical region. Orme et al. (2005) identified nine hotspots of species richness on Earth, defined as the richest $2.5 \%$ of grid cells at a resolution comparable to $1^{\circ}$ latitude $\times 1^{\circ}$ longitude. Six of these nine hotspots are located in the Neotropics (Andes, Amazon Basin, Guiana Highlands, Atlantic coastal forests, Mato Grosso Plateau, Panama, Costa Rica highlands), while two are in the Afrotropics (Western Great Rift Valley, Eastern Great Rift Valley) and the other in the Oriental region (the Himalaya). All hotspots are in tropical regions, and with the exception of the Amazon, all are associated with upland or montane regions that remained forested 
during glacial maxima. Mountains are often exceptionally diverse, although they cover just one eighth of the global land surface, excluding Antarctica; they harbor approximately one third of global terrestrial species diversity (Antonelli 2015).

As with most other biota, avian species diversity is generally greatest in tropical regions near the equator and decreases toward the poles. This so-called latitudinal diversity gradient is considered to be one of the most pervasive large-scale patterns in biology (Jablonski et al. 2017). It cannot be causally linked to a single mechanism and might be the product of diverse drivers. Generally, three different types of mechanisms have been invoked to explain this gradient: ecological, evolutionary, and historical hypotheses (Mittelbach et al. 2007; Pulido-Santacruz and Weir 2016). In the first case, geographical variation in resource availability should constrain diversity, with species carrying capacity decreasing as latitude increases. While evolutionary hypotheses imply that rates of speciation, extinction, and immigration should vary between different latitudes, historical hypotheses focus on the age of ecosystems and the time consequently available for species accumulation, with older ecosystems being considered generally more diverse.

In birds, high species diversity at low latitudes might be associated with low extinction rates (Pulido-Santacruz and Weir 2016). Higher extinction rates at higher latitudes might be related to a global temperature drop at the Eocene-Oligocene boundary (c. $34 \mathrm{Ma}$ ) and to climate perturbations during Plio-Pleistocene glacial cycles (over the last 5 million years). These regions were then repeatedly recolonized from the tropics, which were less affected by climate change, resulting in continuously lower extinction rates.

\subsection{Geography of Speciation}

Species richness within a given area is basically the result of speciation, extinction, and colonization. The latter process involves range expansion via dispersal of a species to an area where it has previously not occurred, followed by establishment of a viable breeding population (Bellemain and Ricklefs 2008). Speciation begins with the accumulation of genetically based divergence between populations and is completed by the formation of reproductive isolation among them. Different species concepts focus on different stages during this speciation continuum (Chap. 2), and different mechanisms can lead to reproductive isolation (Chap. 11). The process of speciation can be approached via different aspects. While one is concerned with processes and mechanisms leading to reproductive isolation (see Chap. 11), another considers speciation within a geographic context (Price 2008; Rundle and Nosil 2005). In birds, and many other organisms, there is usually a phase of geographic separation with no gene flow between diverging populations, termed allopatric speciation (Coyne and Orr 2004). It involves different steps, starting with range expansion, followed by range fragmentation, and the evolution of reproductive isolation between the geographically separated populations, and a further step can 
involve dispersal into a secondary contact zone leading to coexistence in sympatry (Price 2008; Price et al. 2014). Range fragmentation can proceed via vicariance, if the range is split by the formation of a physical barrier resulting from geological events such as montane uplift (Coyne and Orr 2004, see also below). Populations can also become separated by habitat fragmentation through climate change as occurred repeatedly during Pleistocene glacial cycles during the last 2.5 million and particularly last 1 million years when climate fluctuations were most intensive (Hewitt 2000). Allopatry can also be the result of the colonization of a previously unoccupied and isolated area. If it involves the colonization of a small new area such as an oceanic island due to a founder event by a subset of the ancestral population, it is often referred to as peripatric speciation (Coyne and Orr 2004; Lomolino et al. 2010). The lack of gene flow between separated populations during allopatric speciation per se promotes divergence, but different selection pressures caused by ecological differences in the separated populations might accelerate their divergence (Price 2008) (Chap. 11).

It is widely believed that most speciation events in birds involved some phases of allopatry with no gene flow, making allopatric speciation apparently the commonest route for speciation in birds (Phillimore et al. 2008; Price 2008).

Two geographically separated populations can also become reproductively isolated from each other, despite ongoing gene flow at least at the start of their divergence; this is termed parapatric speciation (Coyne and Orr 2004). Three different forms of parapatric speciation have been distinguished (Price 2008). In a model of clinal speciation, adaptation to local environmental conditions could lead to divergence within a population that occurs along an environmental gradient. Speciation can also simply occur as the result of geographic distance, with the population at either end of a continuous distribution area developing steadily greater differences, while intervening populations continue to exchange genes. In the island model of speciation, two populations are separated by a barrier, but the barrier is permeable, and they still exchange genes to some extent. Reproductive isolation can evolve when immigrants (and their offspring) possess low reproductive success or migration itself between adjacent populations is reduced (Price 2008).

A special case of speciation by distance is the ring species model. When an ancestral population spreads around a barrier, adjacent populations might continue to exchange genes, while gene flow between distant populations is gradually reduced. The populations at both ends of the expansion front increasingly diverge, and when they meet after having spread around the barrier, they might have achieved reproductive isolation from each other (cf. Coyne and Orr 2004; Mayr 1942). One avian example where such a process could have been relevant for the diversity currently observed is the Greenish Warbler Phylloscopus trochiloides species complex (Irwin et al. 2005). It has a ringlike distribution around the Tibetan Plateau with five described taxa and an additional, isolated, one in the Caucasus (Alcaide et al. 2014; Irwin et al. 2001, 2005) (Fig. 8.3). A break in morphology, song, and call is most evident between the taxa viridanus and plumbeitarsus north of the Tibetan Plateau. These forms are differentiated genome-wide, whereas the other populations display a genetic gradient around the ring. However, reproductive isolation is not complete in 


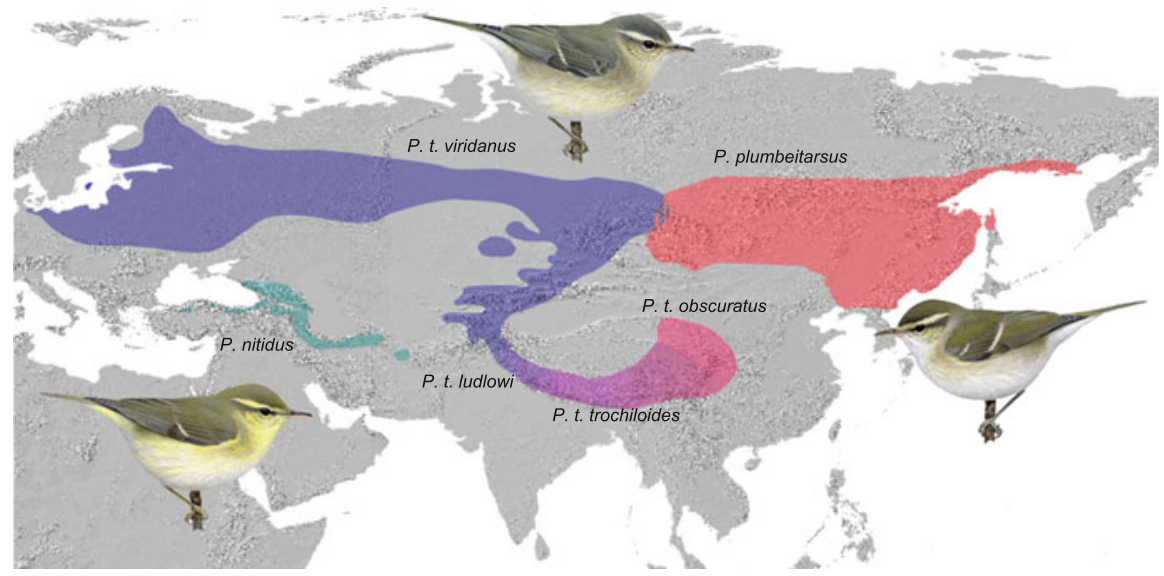

Fig. 8.3 Distribution of the different taxa of the Greenish Warbler Phylloscopus trochiloides species complex. It has a ringlike distribution around the Tibetan Plateau with five described taxa and an additional isolated one in the Caucasus. A break in morphology, song, and call is most evident between viridanus and plumbeitarsus north of the Tibetan Plateau. Distribution areas are modified from BirdLife International and Handbook of the Birds of the World (2016). Bird figures were taken with permission from del Hoyo et al. (2017)

the northern contact zone, and a genomic break in the Southwest can only be explained by secondary contact after divergence in allopatry (Alcaide et al. 2014). Hence, speciation by distance might not entirely explain the ringlike divergence of this complex and climate shifts during the last 1-2 million years which might have led to (repeated) phases of allopatry along the ringlike distribution. Speciation in a ring is indeed difficult to distinguish from secondary contact zones with ongoing gene flow. Such hybridization in secondary contact zones following allopatry have been widely documented in birds (Aliabadian et al. 2005; Weir and Price 2011) (Chap. 10) and might generally be difficult to distinguish from parapatric divergence.

In the case of sympatric speciation, reproductive isolation is achieved without any geographic separation. This model of speciation has been debated for decades, but it can clearly happen under particular, albeit reasonable, biological conditions, as demonstrated by mathematical models (Gavrilets 2014) and empirical works (Savolainen et al. 2006; Sorenson et al. 2003). However, it seems to occur very rarely, and only a few such events in birds can probably be referred to as having happened in sympatry. Most importantly, it must be shown that the divergence of two contemporary and sympatric sister taxa has not involved an allopatric stage. In other words, the initial divergence must have occurred sympatrically, and the possibility of geographic isolation must be eliminated. One of the apparently most plausible sympatric speciation cases in bird concerns African indigobirds of the genus Vidua (Sorenson et al. 2003). This group of songbirds is found in Western and Southern Africa, and they are all host-specific brood parasites, with nestlings reared by waxbills, munias, and allies (Estrildidae) in particular. Male indigobirds learn their songs from their host species, i.e., their foster parents. Females preferentially mate 
with males that mimic the song of their foster parents (Balakrishnan and Sorenson 2006). Unlike in some parasitic cuckoo species where different "host-specific" females mate freely with males, the assortative mating mechanism in indigobirds clearly results in strong cohesion between hosts and parasites. The switch by a female to a new host can then drive simultaneous sympatric divergence as a consequence of learned behavior. Her offspring learn the song from their new host and are most likely to mate with siblings or the offspring from another female that switched to the same new host species (Lovette 2016).

Other proposed examples of speciation without geographic separation concern allochronic speciation, wherein two sister populations diverge due to temporal separation of their breeding periods, as has been suggested on several archipelagos in the Pacific and Atlantic Oceans inhabited by Band-rumped Storm Petrels Oceanodroma castro (Bolton et al. 2008; Monteiro and Furness 1998; Smith et al. 2007) (Chap. 6).

\subsection{Vicariance vs. Dispersal and the Dynamics of Range Evolution in Birds}

Every bird species is restricted to a particular geographic area, i.e., its range, or it occurs in one particular habitat or climatic zone. Ranges differ considerably between different species (see above); nevertheless, strikingly similar distribution patterns can be detected among certain groups. For a long time, vicariance has been invoked to explain such global-scale biogeographic patterns in different bird groups, and vicariance has generally dominated historical biogeography. Vicariance is considered to be the spatial division of a species' range due to the formation of a barrier by historical events such as montane uplift or ocean formation as continents shift (tectonic rifting) (de Queiroz 2005; Lomolino et al. 2010). It was assumed that such historical events might cause congruent biogeographic patterns in different clades through synchronous allopatric speciation events (cf. Halas et al. 2005; Upchurch 2008). As several groups of organisms, including birds, possess distinct Southern Hemisphere distributions, it was hypothesized that vicariant evolution wrought by the breakup of the supercontinent Gondwana from c. 160-30 Ma might explain such biogeographic patterns (e.g. Cracraft 2001; Hedges et al. 1996; Upchurch 2008). This ancient supercontinent in the Southern Hemisphere included the modern-day landmasses of Africa and the Arabian Peninsula, Antarctica, Australia, the Indian subcontinent, Madagascar, and South America.

Palaeognathae have been considered a textbook example of vicariant evolution, and the continental breakup of Gondwana was thought to have shaped their diversification. With the exception of the tinamous of the Neotropical region, all members of the group are flightless, namely, the rheas of South America, the ostriches of Africa and formerly the Arabian Peninsula, the emus and cassowaries of Australasia, and the kiwis of New Zealand as well as the extinct elephant birds of Madagascar 


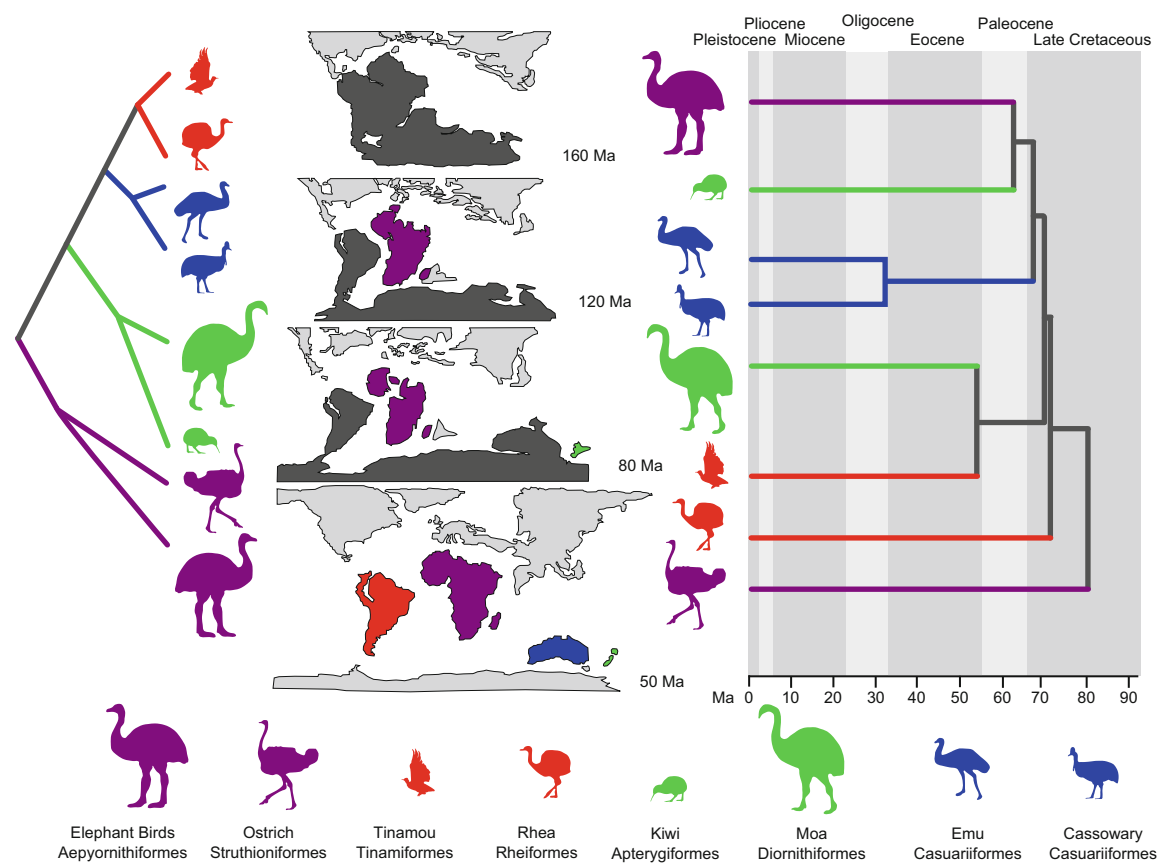

Fig. 8.4 Ratites (Palaeognathae) have for a long time been considered a textbook example of vicariant evolution, and the continental breakup of Gondwana was thought to have shaped their diversification. The breakup of Gondwana during the last 160 million years illustrating the relative position of the continents is shown in the middle, while the cladogram on the left shows the expected phylogenetic relationships of ratites under this scenario. Redrawn after Mitchell et al. (2014) with permission from AAAS. On the right, the most recent time-calibrated phylogenetic hypothesis of ratites based on genomic and morphological data redrawn after Yonezawa et al. (2017) with permission from Elsevier. There is an obvious conflict with the relationships predicted by vicariance through the Gondwana breakup. Moreover, the placement of the tinamous as the closest relatives of the moas meant that the ability to fly must have been lost in several lineages independently

and the extinct moas of New Zealand. However, with the increasing availability of dated molecular phylogenetic hypotheses in the last decade, it became explicitly testable whether branching events along a phylogenetic tree, and their temporality, are congruent with hypothesized drivers of vicariance such as the breakup of Gondwana. The integration in a phylogenetic context of ancient DNA data from the extinct elephant birds and moas revealed a conflict with the relationships predicted by vicariance through the Gondwana breakup (Mitchell et al. 2014) (Fig. 8.4). Moreover, placement of the tinamous as the closest relatives of moas meant that the ability to fly must have been independently lost in several lineages. A recent comprehensive analysis based on genomic and morphological data revealed that Palaeognathae originated in the late Cretaceous in the Northern Hemisphere, migrated to the Southern Hemisphere, and colonized New Zealand and Madagascar 
by over-sea dispersal at a time when these landmasses had already separated from Gondwana (Yonezawa et al. 2017).

Other studies of different bird groups have revealed that dispersal is important in the makeup of regional fauna and that long-distance dispersal and even transoceanic dispersal must be invoked to explain the current distribution patterns of different bird groups such as Columbiformes (pigeons and doves) (Pereira et al. 2007), Psittaciformes (parrots) (Schweizer et al. 2010, 2011), Turdus thrushes (Voelker et al. 2009), cuckoo shrikes and allies (Campephagidae) (Fuchs et al. 2007), and vangas, bush shrikes, and allies (Fuchs et al. 2006).

Although the role of vicariance, especially through continental breakup, has clearly been overestimated in the past, physical barriers as a consequence of landscape changes still might provide ample opportunity for allopatric speciation in birds. However, landscape changes might not lead to congruent temporal diversification among different avian groups, as demonstrated by Smith et al. (2014) in a study of temporal and spatial diversification patterns in 27 lineages of widespread Neotropical birds. The distributions of the taxa in these lineages are interrupted by different landscape barriers such as the Andes, large Amazonian rivers, and the Isthmus of Panama. However, no synchronous divergence across these different barriers was found among the different taxa analyzed, and consequently no congruent effect of landscape changes was revealed. Rather, the barriers were semipermeable within a geographically structured landscape matrix. Diversity was strongly correlated to the age of the corresponding lineage. This indicated that lineages that had persisted for a longer time period within a given landscape had more time to disperse across barriers and hence greater opportunity to differentiate across them. Additionally, ecology had a significant effect on lineage diversity. Lineages with low dispersal ability occupying the understory were significantly more diverse than more mobile groups inhabiting the canopy of tropical forests. Or, lineages with low dispersal ability seem to have accumulated genetic differences at a higher rate. Overall, diversification patterns in these Neotropical avian lineages are the result of interactions between the ecological properties of the different lineages and their environment as well as the age of a given lineage and are only indirectly influenced by landscape changes. This highlights the role of dispersal as a primary driver for allopatric speciation in birds (Smith et al. 2014).

In general, dispersal accelerates geographic range expansions in birds, and the rate at which sister lineages achieve sympatric ranges following speciation in spatial segregation is correlated with their dispersal ability (Pigot and Tobias 2015). Therefore, dispersal is of general importance for shaping species assemblages over space and time.

Physical barriers, time, and dispersal ability, however, are not the only factors that limit colonization of new areas and the dynamics of range expansions in birds. Geographic ranges are generally limited by a suite of biotic and abiotic factors (see also Chaps. 9 and 12) including climate, habitat constraints, food and nest sites, predators, and parasites and pathogens, as well as competition (Koenig 2016; Newton 2003). Among birds in general, ranges at higher latitudes might be strongly limited by winter temperatures, whereas competition might be more important in the tropics (Newton 2003). However, the relative importance of biotic factors in limiting 
species distributions is controversial (Pigot and Tobias 2013), not least because interspecific competition is difficult to detect in field studies and is not easily tested for in controlled experiments (Greenberg 2016).

However, phylogenies combined with ecological information can be used to test for the role of competition in limiting species ranges. In a study of ovenbirds (Furnariidae), including woodcreepers, a species-rich and ecologically diverse family of Neotropical birds, Pigot and Tobias (2013) showed that rates of secondary sympatry increase with time following diversification in pairs of sister species. This indicates that biotic interactions could be important in limiting range overlap between closely related species, assuming that lineages become more ecologically divergent the longer they are separated. In congruence, accelerated transition rates to sympatry were also revealed between species pairs that differ in ecomorphology related to resource use and foraging strategy. Biotic interactions also play a role in the growth of species diversity at the community level among songbirds in the Eastern Himalayas. Diversification appears to be limited by a failure of new species to expand their ranges and to colonize the local area, caused by competitive biotic interactions as a result of the available niche space being filled (Price et al. 2014).

Range expansion is not only an important first step in speciation; it also influences the number of coexisting species after lineages have diverged ecologically and/or achieved reproductive isolation in allopatry. It thus shapes the turnover of biodiversity in space and time. Understanding the evolutionary dynamics of range expansions and range limits is consequently one of the prerequisites for predicting range shifts and biodiversity patterns under ongoing human-induced climate change (Chap. 12).

Acknowledgments We thank Elisa Badia, Erina Balmer, Vanesa de Pietri, Jana Flury, Guy M. Kirwan, Stephan Lauper, and Christian Müller for their help in preparing this chapter.

\section{References}

Alcaide M, Scordato ESC, Price TD, Irwin DE (2014) Genomic divergence in a ring species complex. Nature 511:83-U433

Aliabadian M, Roselaar CS, Nijman V, Sluys R, Vences M (2005) Identifying contact zone hotspots of passerine birds in the Palaearctic region. Biol Lett 1:21-23

Alroy J (2008) Dynamics of origination and extinction in the marine fossil record. Proc Natl Acad Sci USA 105:11536-11542

Antonelli A (2015) Biodiversity: multiple origins of mountain life. Nature 524:300-301

Balakrishnan CN, Sorenson MD (2006) Song discrimination suggests premating isolation among sympatric indigobird species and host races. Behav Ecol 17:473-478

Bass MS, Finer M, Jenkins CN, Kreft H, Cisneros-Heredia DF, McCracken SF, Pitman NCA, English PH, Swing K, Villa G, Di Fiore A, Voigt CC, Kunz TH (2010) Global conservation significance of Ecuador's Yasuni National Park. PLoS One 5:e8767

Bellemain E, Ricklefs RE (2008) Are islands the end of the colonization road? Trends Ecol Evol 23:461-468 
BirdLife International and Handbook of the Birds of the World (2016) Bird species distribution maps of the world. Version 6.0. Available at http://datazone.birdlife.org/species/requestdis

Bolton M, Smith AL, Gomez-Diaz E, Friesen VL, Medeiros R, Bried J, Roscales JL, Furness RW (2008) Monteiro's Storm-petrel Oceanodroma monteiroi: a new species from the Azores. IBIS 150:717-727

Brown JW, Rest JS, Garcia-Moreno J, Sorenson MD, Mindell DP (2008) Strong mitochondrial DNA support for a Cretaceous origin of modern avian lineages. BMC Biol 6:6

Bryson RW, Chaves J, Smith BT, Miller MJ, Winker K, Pérez-Emán JL, Klicka J (2014) Diversification across the New World within the 'blue' cardinalids (Aves: Cardinalidae). J Biogeogr 41:587-599

Collar N, Sharpe CJ (2017) Sombre Rockchat (Oenanthe dubia). In: del Hoyo J, Elliott A, Sargatal J, Christie DA, de Juana E (eds) Handbook of the birds of the world alive. Lynx Edicions, Barcelona (retrieved from http://www.hbw.com/node/58530 on 18 September 2017)

Cooper A, Penny D (1997) Mass survival of birds across the Cretaceous-Tertiary boundary: molecular evidence. Science 275:1109-1113

Coyne JA, Orr HA (2004) Speciation. Sinauer Associates, Sunderland

Cracraft J (2001) Avian evolution, Gondwana biogeography and the Cretaceous-Tertiary mass extinction event. Proc R Soc B Biol Sci 268:459-469

de Queiroz A (2005) The resurrection of oceanic dispersal in historical biogeography. Trends Ecol Evol 20:68-73

del Hoyo J, Collar NJ (2014) HBW and BirdLife International illustrated checklist of the birds of the world. Vol 1: No-passerines. Lynx Edicions, Barcelona

del Hoyo J, Elliott A, Sargatal J, Christie DA, de Juana E (eds) (2017) Handbook of the birds of the world alive. Lynx Edicions, Barcelona (retrieved from http://www.hbw.com/ on 14/02/2017)

Derryberry EP, Claramunt S, Derryberry G, Chesser RT, Cracraft J, Aleixo A, Pérez-Emán J, Remsen JJV, Brumfield RT (2011) Lineage diversification and morphological evolution in a large-scale continental radiation: the Neotropical ovenbirds and woodcreepers (Aves: Furnariidae). Evolution 65:2973-2986

Feduccia A (1995) Explosive evolution in Tertiary birds and mammals. Science 267:637-638

Feduccia A (2003) 'Big bang' for Tertiary birds? Trends Ecol Evol 18:172-176

Ficetola GF, Mazel F, Thuiller W (2017) Global determinants of zoogeographical boundaries. Nat Ecol Evol 1:00089

Fuchs J, Fjeldså J, Pasquet E (2006) An ancient African radiation of corvoid birds (Aves: Passeriformes) detected by mitochondrial and nuclear sequence data. Zool Scr 35:375-385

Fuchs J, Cruaud C, Couloux A, Pasquet E (2007) Complex biogeographic history of the cuckooshrikes and allies (Passeriformes: Campephagidae) revealed by mitochondrial and nuclear sequence data. Mol Phylogenet Evol 44:138-153

Gavrilets S (2014) Models of speciation: where are we now? J Hered 105:743-755

Greenberg RS (2016) Bird communities. In: Lovette IJ, Fitzpatrick JW (eds) The Cornell Lab of Ornithology handbook of bird biology, 3rd edn. Wiley, Cornell University, pp 537-577

Hackett SJ, Kimball RT, Reddy S, Bowie RCK, Braun EL, Braun MJ, Chojnowski JL, Cox WA, Han KL, Harshman J, Huddleston CJ, Marks BD, Miglia KJ, Moore WS, Sheldon FH, Steadman DW, Witt CC, Yuri T (2008) A phylogenomic study of birds reveals their evolutionary history. Science 320:1763-1768

Halas D, Zamparo D, Brooks DR (2005) A historical biogeographical protocol for studying biotic diversification by taxon pulses. J Biogeogr 32:249-260

Hedges SB, Parker PH, Sibley CG, Kumar S (1996) Continental breakup and the ordinal diversification of birds and mammals. Nature 381:226-229

Hewitt G (2000) The genetic legacy of the Quaternary ice ages. Nature 405:907-913

Holt B, Lessard JP, Borregaard MK, Fritz SA, Araujo MB, Dimitrov D, Fabre PH, Graham CH, Graves GR, Jonsson KA, Nogues-Bravo D, Wang ZH, Whittaker RJ, Fjeldså J, Rahbek C (2013) An update of Wallace's zoogeographic regions of the world. Science 339:74-78

Irwin DE, Bensch S, Price TD (2001) Speciation in a ring. Nature 409:333-337 
Irwin DE, Bensch S, Irwin JH, Price TD (2005) Speciation by distance in a ring species. Science 307:414-416

Jablonski D, Huang S, Roy K, Valentine JW (2017) Shaping the latitudinal diversity gradient: new perspectives from a synthesis of paleobiology and biogeography. Am Nat 189:1-12

Jarvis ED, Mirarab S, Aberer AJ, Li B, Houde P, Li C, Ho SYW, Faircloth BC, Nabholz B, Howard JT, Suh A, Weber CC, da Fonseca RR, Li JW, Zhang F, Li H, Zhou L, Narula N, Liu L, Ganapathy G, Boussau B, Bayzid MS, Zavidovych V, Subramanian S, Gabaldon T, CapellaGutierrez S, Huerta-Cepas J, Rekepalli B, Munch K, Schierup M, Lindow B, Warren WC, Ray D, Green RE, Bruford MW, Zhan XJ, Dixon A, Li SB, Li N, Huang YH, Derryberry EP, Bertelsen MF, Sheldon FH, Brumfield RT, Mello CV, Lovell PV, Wirthlin M, Schneider MPC, Prosdocimi F, Samaniego JA, Velazquez AMV, Alfaro-Nunez A, Campos PF, Petersen B, Sicheritz-Ponten T, Pas A, Bailey T, Scofield P, Bunce M, Lambert DM, Zhou Q, Perelman P, Driskell AC, Shapiro B, Xiong ZJ, Zeng YL, Liu SP, Li ZY, Liu BH, Wu K, Xiao J, Yinqi X, Zheng QM, Zhang Y, Yang HM, Wang J, Smeds L, Rheindt FE, Braun M, Fjeldså J, Orlando L, Barker FK, Jonsson KA, Johnson W, Koepfli KP, O'Brien S, Haussler D, Ryder OA, Rahbek C, Willerslev E, Graves GR, Glenn TC, McCormack J, Burt D, Ellegren H, Alström P, Edwards SV, Stamatakis A, Mindell DP, Cracraft J, Braun EL, Warnow T, Jun W, Gilbert MTP, Zhang GJ (2014) Whole-genome analyses resolve early branches in the tree of life of modern birds. Science 346:1320-1331

Jetz W, Thomas GH, Joy JB, Hartmann K, Mooers AO (2012) The global diversity of birds in space and time. Nature 491:444-448

Jonsson KA, Fabre PH, Fritz SA, Etienne RS, Ricklefs RE, Jorgensen TB, Fjeldså J, Rahbek C, Ericson PGP, Woog F, Pasquet E, Irestedt M (2012) Ecological and evolutionary determinants for the adaptive radiation of the Madagascan vangas. Proc Natl Acad Sci USA 109:6620-6625

Koenig WD (2016) Ecology of bird populations. In: Lovette IJ, Fitzpatrick JW (eds) The Cornell Lab of Ornithology handbook of bird biology, 3rd edn. Wiley, Cornell University, pp 495-534

Kreft H, Jetz W (2010) A framework for delineating biogeographical regions based on species distributions. J Biogeogr 37:2029-2053

Liu Y, Hu JH, Li SH, Duchen P, Wegmann D, Schweizer M (2016) Sino-Himalayan mountains act as cradles of diversity and immigration centres in the diversification of parrotbills (Paradoxornithidae). J Biogeogr 43:1488-1501

Livezey BC, Zusi RL (2007) Higher-order phylogeny of modern birds (Theropoda, Aves: Neornithes) based on comparative anatomy. II. Analysis and discussion. Zool J Linnean Soc 149:1-95

Lomolino MV, Riddle BR, Whittaker RJ, Brown JH (2010) Biogeography, 4th edn. Sinauer Associates, Sunderland

Lovette IJ (2016) How birds evolve. In: Lovett JC, Fitzpatrick JW (eds) The Cornell Lab of Ornithology handbook of bird biology, 3rd edn. Wiley, Cornell University, pp 63-99

Mayr E (1942) Systematics and the origin of species. Columbia University Press, New York

Mayr G (2011) Metaves, Mirandornithes, Strisores and other novelties - a critical review of the higher-level phylogeny of neornithine birds. J Zool Syst Evol Res 49:58-76

Mayr G (2017) Avian evolution: the fossil record of birds and its paleobiological significance. Wiley, Chichester, West Sussex

Mitchell KJ, Llamas B, Soubrier J, Rawlence NJ, Worthy TH, Wood J, Lee MSY, Cooper A (2014) Ancient DNA reveals elephant birds and kiwi are sister taxa and clarifies ratite bird evolution. Science 344:898-900

Mittelbach GG, Schemske DW, Cornell HV, Allen AP, Brown JM, Bush MB, Harrison SP, Hurlbert AH, Knowlton N, Lessios HA, McCain CM, McCune AR, McDade LA, McPeek MA, Near TJ, Price TD, Ricklefs RE, Roy K, Sax DF, Schluter D, Sobel JM, Turelli M (2007) Evolution and the latitudinal diversity gradient: speciation, extinction and biogeography. Ecol Lett 10:315-331 
Monteiro LR, Furness RW (1998) Speciation through temporal segregation of Madeiran storm petrel (Oceanodroma castro) populations in the Azores? Philos Trans R Soc Lond Ser B Biol Sci 353:945-953

Newton I (2003) The speciation and biogeography of birds. Academic Press, London

Orme CDL, Davies RG, Burgess M, Eigenbrod F, Pickup N, Olson VA, Webster AJ, Ding TS, Rasmussen PC, Ridgely RS, Stattersfield AJ, Bennett PM, Blackburn TM, Gaston KJ, Owens IPF (2005) Global hotspots of species richness are not congruent with endemism or threat. Nature 436:1016-1019

Pacheco MA, Battistuzzi FU, Lentino M, Aguilar R, Kumar S, Escalante AA (2011) Evolution of modern birds revealed by mitogenomics: timing the radiation and origin of major orders. Mol Biol Evol 28:1927-1942

Pereira SL, Baker AJ (2006) A mitogenomic timescale for birds detects variable phylogenetic rates of molecular evolution and refutes the standard molecular clock. Mol Biol Evol 23:1731-1740

Pereira SL, Johnson KP, Clayton DH, Baker AJ (2007) Mitochondrial and nuclear DNA sequences support a Cretaceous origin of Columbiformes and a dispersal-driven radiation in the Paleogene. Syst Biol 56:656-672

Phillimore AB, Price TD (2008) Density-dependent cladogenesis in birds. PLoS Biol 6:483-489

Phillimore AB, Orme CDL, Thomas GH, Blackburn TM, Bennett PM, Gaston KJ, Owens IPF (2008) Sympatric speciation in birds is rare: insights from range data and simulations. Am Nat 171:646-657

Pigot AL, Tobias JA (2013) Species interactions constrain geographic range expansion over evolutionary time. Ecol Lett 16:330-338

Pigot AL, Tobias JA (2015) Dispersal and the transition to sympatry in vertebrates. Proc R Soc B Biol Sci 282:20141929

Pratt RC, Gibb GC, Morgan-Richards M, Phillips MJ, Hendy MD, Penny D (2009) Toward resolving deep Neoaves phylogeny: data, signal enhancement, and priors. Mol Biol Evol 26:313-326

Price T (2008) Speciation in birds. Roberts and Company, Greenwood Village, CO

Price TD, Hooper DM, Buchanan CD, Johansson US, Tietze DT, Alström P, Olsson U, GhoshHarihar M, Ishtiaq F, Gupta SK, Martens J, Harr B, Singh P, Mohan D (2014) Niche filling slows the diversification of Himalayan songbirds. Nature 509:222-225

Prum RO, Berv JS, Dornburg A, Field DJ, Townsend JP, Lemmon EM, Lemmon AR (2015) A comprehensive phylogeny of birds (Aves) using targeted next-generation DNA sequencing. Nature 526:569-U247

Pulido-Santacruz P, Weir JT (2016) Extinction as a driver of avian latitudinal diversity gradients. Evolution 70:860-872

Rabosky DL (2009) Ecological limits and diversification rate: alternative paradigms to explain the variation in species richness among clades and regions. Ecol Lett 12:735-743

Rabosky DL, Lovette IJ (2008) Density-dependent diversification in North American wood warblers. Proc R Soc B Biol Sci 275:2363-2371

Reddy S, Driskell A, Rabosky DL, Hackett SJ, Schulenberg TS (2012) Diversification and the adaptive radiation of the vangas of Madagascar. Proc R Soc B Biol Sci 279:2062-2071

Rundle HD, Nosil P (2005) Ecological speciation. Ecol Lett 8:336-352

Savolainen V, Anstett MC, Lexer C, Hutton I, Clarkson JJ, Norup MV, Powell MP, Springate D, Salamin N, Baker WJ (2006) Sympatric speciation in palms on an oceanic island. Nature 441:210-213

Schulte P, Alegret L, Arenillas I, Arz JA, Barton PJ, Bown PR, Bralower TJ, Christeson GL, Claeys P, Cockell CS, Collins GS, Deutsch A, Goldin TJ, Goto K, Grajales-Nishimura JM, Grieve RAF, Gulick SPS, Johnson KR, Kiessling W, Koeberl C, Kring DA, MacLeod KG, Matsui T, Melosh J, Montanari A, Morgan JV, Neal CR, Nichols DJ, Norris RD, Pierazzo E, Ravizza G, Rebolledo-Vieyra M, Reimold WU, Robin E, Salge T, Speijer RP, Sweet AR, Urrutia-Fucugauchi J, Vajda V, Whalen MT, Willumsen PS (2010) The Chicxulub asteroid impact and mass extinction at the Cretaceous-Paleogene boundary. Science 327:1214-1218 
Schweizer M, Seehausen O, Güntert M, Hertwig ST (2010) The evolutionary diversification of parrots supports a taxon pulse model with multiple trans-oceanic dispersal events and local radiations. Mol Phylogenet Evol 54:984-994

Schweizer M, Seehausen O, Hertwig ST (2011) Macroevolutionary patterns in the diversification of parrots: effects of climate change, geological events and key innovations. J Biogeogr 38:2176-2194

Schweizer M, Hertwig ST, Seehausen O (2014) Diversity versus disparity and the role of ecological opportunity in a continental bird radiation. J Biogeogr 41:1301-1312

Slack KE, Jones CM, Ando T, Harrison GL, Fordyce RE, Arnason U, Penny D (2006) Early penguin fossils, plus mitochondrial genomes, calibrate avian evolution. Mol Biol Evol 23:1144-1155

Smith AL, Monteiro L, Hasegawa O, Friesen VL (2007) Global phylogeography of the bandrumped storm-petrel (Oceanodroma castro; Procellariiformes: Hydrobatidae). Mol Phylogenet Evol 43:755-773

Smith BT, McCormack JE, Cuervo AM, Hickerson MJ, Aleixo A, Cadena CD, Perez-Eman J, Burney CW, Xie X, Harvey MG, Faircloth BC, Glenn TC, Derryberry EP, Prejean J, Fields S, Brumfield RT (2014) The drivers of tropical speciation. Nature 515:406-409

Sorenson MD, Sefc KM, Payne RB (2003) Speciation by host switch in brood parasitic indigobirds. Nature 424:928-931

Suh A (2016) The phylogenomic forest of bird trees contains a hard polytomy at the root of Neoaves. Zool Scr 45:50-62

Upchurch P (2008) Gondwanan break-up: legacies of a lost world? Trends Ecol Evol 23:229-236

Vilhena DA, Antonelli A (2015) A network approach for identifying and delimiting biogeographical regions. Nat Commun 6:6848

Voelker G, Rohwer S, Outlaw DC, Bowie RCK (2009) Repeated trans-Atlantic dispersal catalysed a global songbird radiation. Glob Ecol Biogeogr 18:41-49

Wallace AR (1867) The geographical distribution of animals. Harper, New York

Weir JT (2006) Divergent timing and patterns of species accumulation in lowland and highland Neotropical birds. Evolution 60:842-855

Weir JT, Price TD (2011) Limits to speciation inferred from times to secondary sympatry and ages of hybridizing species along a latitudinal gradient. Am Nat 177:462-469

Winkler DW, Billerman SM, Lovette IJ (2015) Bird families of the world: an invitation to the spectacular diversity of birds. Lynx Edicions, Barcelona

Yonezawa T, Segawa T, Mori H, Campos PF, Hongoh Y, Endo H, Akiyoshi A, Kohno N, Nishida S, Wu JQ, Jin HF, Adachi J, Kishino H, Kurokawa K, Nogi Y, Tanabe H, Mukoyama H, Yoshida K, Rasoamiaramanana A, Yamagishi S, Hayashi Y, Yoshida A, Koike H, Akishinonomiya F, Willerslev E, Hasegawa M (2017) Phylogenomics and morphology of extinct Paleognaths reveal the origin and evolution of the ratites. Curr Biol 27:68-77

Open Access This chapter is licensed under the terms of the Creative Commons Attribution 4.0 International License (http://creativecommons.org/licenses/by/4.0/), which permits use, sharing, adaptation, distribution and reproduction in any medium or format, as long as you give appropriate credit to the original author(s) and the source, provide a link to the Creative Commons license and indicate if changes were made.

The images or other third party material in this chapter are included in the chapter's Creative Commons license, unless indicated otherwise in a credit line to the material. If material is not included in the chapter's Creative Commons license and your intended use is not permitted by statutory regulation or exceeds the permitted use, you will need to obtain permission directly from the copyright holder.

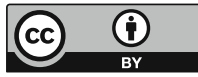

